\title{
Thin layer chromatography, high performance liquid chromatography and melting point for extraction and purification of cinnamic acid from cinnamon bark (Cinnamon aromaticum)
}

\author{
Nibal Kh. Mousa ${ }^{1}$, Abdal-Jbbar A. Abow ${ }^{1}$, Safauldee A. Abdul-Rahman ${ }^{1}$, Ishrak Ab. Ali $^{2}$, \\ Akeel M. Ahmed ${ }^{1}$ \\ ${ }^{1}$ Ministry of Science and Technology. Baghdad, Iraq. \\ ${ }^{2}$ The National Center for Drug Control and Research, Ministry of Health. Baghdad, Iraq
}

Rec. 28 Aug, 2012 Accpt. 30 Sept, 2012

\begin{abstract}
The aim of this study to purified the cinnamic acid from the cinnamon bark. The partial purified cinnamic acid is obtained after column chromatography application. Thin layer chromatography (TLC) elution yielded pure crystals, which identified as cinnamic acid in comparison with the standard cinnamic acid $10.5 \mathrm{mg} / 150 \mathrm{gm}$ cinnamon bark powder obtain as a result of partial purification by TLC. Chemical tests for identification compound of extract crystals yield were included: general tests for phenolic compound, HPLC (High performance Liquid Chromatography) analysis and melting point estimation, in relation to standard cinnamic acid for tests. Concentration of cinnamic acid was $96 \%$.
\end{abstract}

Keywords: Cinnamon, cinnamic acid, TLC, HPLC.

\section{Introduction}

In ancient Egypt, cinnamon was mainly used as medicine and as a flavoring for beverages. One main use of cinnamon was for embalming of the deceased as body cavities were filled with spices and preserves. In ancient Rome, Nero, an emperor in first century A.D., burned year's supply of cinnamon on his wife's funeral pyre (Gray \& Miller, 1970). This was considered as extravagant gestures meant to signify the depth of his loss. Cinnamon was often paired with ginger in Medieval Europe, as most meals were prepared in a single cauldron and were casseroles containing both meat and fruit. It was also used as a bridge for flavors, and also mention in Bible. Cinnamon distributed through the world, but particularly suited to the warm, tropical locales of south India, Southeast Asia and Brazil. Most are evergreen but some, including the North America Sassafras, are deciduous (Robert et al., 1996).

There are approximately between 50 to 250 different species of cinnamon. It's beautiful ornamental tree with golden red bark that is dried and is the cinnamon spice. New foliage is deep red, and small white flowers are followed by dark purple fruit. The tree is small or medium sized, usually $(15-20 \mathrm{~m})$, It will survive short frosts and temperatures to $32 \mathrm{~F}$, protect from hard freezes and prolonged cool weather, propagation by seeds, harvest after 1-2 years from planting (Al-Shamaa, 19890). the cinnamon is full with vitamins such as vitamins $A$ and $B_{3}$, besid the minerals table (1). Cinnamon still known as "Kwai "in Chinese language. It botanical name derives from the Hebraic and Arabic term a" momon "meaning fragrant spice plant.In ancient Egyptians known "cannon". Italians called it "canella" meaning "littletube", Germany known "Zimt", The name cinnamon comes from Phoenician and Hebrew through the Greek kinnámōmon. In Malayalam, it is called Karuva. In many other, particularly European, languages it has a name akin to French cannelle, diminutive of canne from its tube-like shape. In Persian, it is called darchin literary meaning taken, picked from tree (Dastur, 1977).

\footnotetext{
* Corresponding author:

Dr. Nibal Khaleel Mousa

$\bowtie$ nwhiteflower79@yahoo.com
} 


\begin{tabular}{|c|c|c|}
\hline & Nutrients & Amount \\
\hline \multirow[t]{2}{*}{1.} & Basic components & \multirow[b]{2}{*}{$0.16 \mathrm{gm}, 3.6 \mathrm{gm}, 0.44 \mathrm{gm}, 0.16 \mathrm{gm}$} \\
\hline & Protein, Carbohydrate, Water, Ash. & \\
\hline \multirow[t]{2}{*}{2.} & Calories & \multirow[b]{2}{*}{$11.8 \mathrm{gm}, 1.2 \mathrm{gm}, 3.6 \mathrm{gm}, 0.16 \mathrm{gm}$} \\
\hline & $\begin{array}{l}\text { Total calories, Calories from fat, Calories from } \\
\text { carbohydrate, Calories from protein. }\end{array}$ & \\
\hline \multirow[t]{2}{*}{3.} & Fats & \multirow[b]{2}{*}{$0.16 \mathrm{gm}, 0.04 \mathrm{gm}, 0.04 \mathrm{gm}, 0.04 \mathrm{gm}$} \\
\hline & Total fats, Saturated fats, Mono fats, Poly fats. & \\
\hline \multirow[t]{2}{*}{4.} & Vitamins & \multirow[b]{2}{*}{$\begin{array}{l}7.08 \mathrm{mcg}, 0.04 \mathrm{gm}, 1.44 \mathrm{mcg}, 1.32 \mathrm{mcg}, 0.04 \\
\mathrm{gm}\end{array}$} \\
\hline & $\begin{array}{l}\text { Vitamin A, Vitamin B3, Vitamin K, Folate, Niacin } \\
\text { equid. }\end{array}$ & \\
\hline \multirow[t]{2}{*}{5.} & Minerals & \multirow[b]{2}{*}{$\begin{array}{l}55.64 \mathrm{mg}, 1.72 \mathrm{mg}, 2.52 \mathrm{mg}, 0.76 \mathrm{mg}, 2.8 \mathrm{mg} \text {, } \\
22.68 \mathrm{mg}, 0.04 \mathrm{mcg}, 1.2 \mathrm{mg}, 0.08 \mathrm{mg} \text {. }\end{array}$} \\
\hline & $\begin{array}{l}\text { Calcium, Iron, Magnesium, Manganese, Phosphorum, } \\
\text { Potassium, Selenium, Sodium, Zinc. }\end{array}$ & \\
\hline
\end{tabular}

Table (1): Cinnamon Nutrition Facts: In $4.52 \mathrm{~g}$ of Cinnamon can find.

The tree is small or medium sized, usually (15-20m), It will survive short frosts and temperatures to $32 \mathrm{~F}$, protect from hard freezes and prolonged cool weather, propagation by seeds, harvest after 1-2 years from planting (Al-Shamaa, 1989). the cinnamon is full with vitamins such as vitamins $\mathrm{A}$ and $\mathrm{B}_{3}$, besid the minerals. Mainly there are two kinds of cinnamon: Ceylon cinnamon such as Cinnamomum verum, Cinnamomum zeylanicum .Many consider Ceylon cinnamon the true cinnamon. Ceylon variety is more refined and subtle, Implant in Sirlanka and the west beach of India, it's called in markets cinnamon chips. The bark is light yellow, thin,rather creamy, aqueos extract is active, but alcoholic extract is more bio-activity. Volatile oil containing $75 \%$ of Cinnamicaldehyde component and 8\% from Eugenol, while found that the volatile oil contain 34 component, $78 \%$ TerpeneHydrocarbons, 9\% OxygenatedTerpenodanoids and has suggested that volatile oil has an antioxidant activity rate $(55.94 \%-66.9 \%)$ in $100-200 \mathrm{ppm}$ on succession (Al-Zubaidi, 2005). and Chinese cinnamon which is the famous genus related to Chinese cinnamon is Cinnamomu aromaticum. Some of their synonyms are cassia cinnamon, cassia lignea, consist from the dried peel of cinnamon cassia blume, the original home is in China, but planting in India, Vietnam and Indonesia. The bark is peel off, dried and allows to form a roll-the cinnamon stick that known todays, harder than the Ceylon cinnamon and containing cinnamicaldehyde and eugenol with bitty amount and may be not (Al-Zubaidi, 2005).
Pure cinnamic acid is a white crystalline hydroxycinnamic acid and the most sonynames was phenyl acrylic acid, 3Phenyl- propanic acid, 3-Phenylacrylic acid, Cinnama. The chemical formula $\mathrm{C}_{9} \mathrm{H}_{8} \mathrm{O}_{2}$. Cinnamic acid is slightly soluble in water and boiling at $300 \dot{C}$ table (2) (Camarat et al., 2006). It is obtained from oil of cinnamon, or from balsams such as storax. It is also found in Shea butter and is the best indication of its environmental history and post-extraction conditions. It can also be made synthetically. Cinnamic acid is used in flavors, synthetic indigo and certain pharmaceuticals, though its primary used in the manufacturing of the methyl, ethyl, and benzyl esters for the perfume industry. Cinnamic acid has a "honey, floral odor" and more volatile ethyl ester (ethyl cinnamate) that flavor components in the essential oil of cinnamon, in which related cinnamaldehyde is the major constituent. Cinnamic acid is also part of the biosynthetic shikimate and phenylpropanoide pathways. Cinnamic acid is soluble in diethyl ether, insoluble in hexane (Chen et al., 2005).

\begin{tabular}{|c|c|}
\hline Chemical formula & $\mathbf{C}_{\mathbf{9}} \mathbf{H}_{\mathbf{8}} \mathbf{O}_{\mathbf{2}}$ \\
\hline Molar mass & $148.17 \mathrm{gm} / \mathrm{mol}$ \\
\hline Appearance & mono clinic crystals \\
\hline Density & $1.2475 \mathrm{gm} / \mathrm{cm}^{3}$ \\
\hline Melting point & $132-135 \dot{\mathrm{C}}$ \\
\hline Boiling point & $300 \dot{\mathrm{C}}$ \\
\hline \multicolumn{2}{|c|}{ Solubility in } \\
\hline Water & $0.4 \mathrm{gm} / \mathrm{L}(20 \dot{\mathrm{C}})$ \\
\hline Chloroform & $0.93 \mathrm{M}$ \\
\hline Ethanol & $0.86 \mathrm{M}$ \\
\hline Methanol & $1.1 \mathrm{M}$ \\
\hline Acidity (PKa) & 4.44 \\
\hline Molecular Weight & 148.1586 \\
\hline Stability & $\begin{array}{c}\text { Stable under ordinary } \\
\text { condition }\end{array}$ \\
\hline
\end{tabular}

Table (2): Properties of cinnamic acid 
In the last searches (Mousa et al., 2011; Mousa et al., 2011). cinnamic acid improved ability to be a vaccine as antioxidant and Hepatoprotectivity against pro-drug cytoxan. So, we looking for extraction and purification with the cheapest and easiest ways to recommendation in the future the dose from cinnamon to patients gain as much as could from cinnamon bark rich with.

\section{Material \& Methods:}

The partial purified cinnamic acid happened after column chromatography application. Thin layer chromatography elution yield pure crystals, which identified as cinnamic acid in comparison with the standard cinnamic acid. Chemical tests for identification compound of extract crystals yield were included: general tests for phenolic compound, HPLC (High Performance Liquid Chromatography) analysis and melting point estimation, in relation to standard cinnamic acid for tests.

\section{Collection of the samples:}

Cinnamon plant were collected from the local market then kept in cool dark place until used to avoid losing some compound from the bark by vaporizing such as cinnamicaldehyde (Jayaprakash et al., 2002).

\section{Preparation of the cinnamon barks} extraction:

Mixed $150 \mathrm{gm}$ of cinnamon bark powder with $2.5 \mathrm{~L}$ methanol for $72 \mathrm{hrs}$. in cool dark

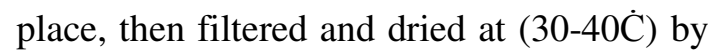
rotary evaporator to obtain $1 / 10$ from the original volume and stored at $20 \dot{\mathrm{C}}$ till the next steps. All these steps were alone away from direct light and extensive stress that led to oxidation of the plant extract (O'Neil, 2006).

\section{Detection of polyphenol groups:}

Phenolic group $\left(\mathrm{C}_{9} \mathrm{H}_{8} \mathrm{OH}\right)$ was detected after dissolving in $\mathrm{NaOH} \mathrm{5 \%}$, by change the color from colorless to any color due to oxidation. Phenolic group in molecules can be determined by the following tests.

I. Ferric chloride test: Phenolic group was detected by adding $1 \%$ aqueous or alcohol ferric chloride and change the color to green, purple, blue or black $\left(\mathrm{O}^{\prime}\right.$ Neil, 2006).

II. Libermann reaction: Phenolic group with a free para position can be detected by libermann reaction, which included addition $1 \mathrm{ml}$ conc. $\mathrm{H}_{2} \mathrm{SO}_{4}$ and a few crystal of $\mathrm{NaNO}_{2}$, production of green or blue-violet color immediately indicates the presence of phenolic group (Moffat, 2004).

III. Phthalein test: Phthalein test was done by adding 2 drops of conc. $\mathrm{H}_{2} \mathrm{SO}_{4}$ to phenolic compound sample, then heated and poured to $\mathrm{NaOH} 10 \%$, production of a red, blue, high green and colourless indicates the presence of phenol, catechol and hydroquinone, $\alpha$ and $\beta$ Naphthol and p-cresol, respectively (Moffat, 2004).

IV. Specific Reaction of Benzene (Aromatic Ring) Aluminium chloride $\left(\mathrm{AlCl}_{3}\right)$ test (Friedle graft): Get $0.1 \mathrm{gm}$ of the unknown in $1 \mathrm{ml}$ of chloroform, then added a pinch of anhydrous $\mathrm{AlCl}_{3}$ with a spatula along the sides of the test tube, crystals of $\mathrm{AlCl}_{3}$ became yellow but turn dark orange within few minutes and the chloroform layer is colourless (Moffat, 2004).

V. Specific test for double bond: In order to find out unsaturated compound examined the following two tests (Moffat, 2004).

A. Bromine decolourisation test: $0.1 \mathrm{gm}$ of unknown was added with shaking to $2 \mathrm{ml}$ carbon tetrachloride contained a 5\% solution of bromine, Disappear the reddish brown colour is a positive test for unsaturated compound.

\section{B. The Baeyer test:}

Baeyer reagent (alkaline $\mathrm{KMnO}_{4}$ solution) was added to solution of $0.1 \mathrm{gm}$ compound and $2 \mathrm{ml}$ water or ethanol, with shaking. Disappearance of purple color indicates the unsaturated compound.

Isolation \& purification of cinnamic acid:

Cinnamic acid can be oxidized and converted to other benzoic compounds (O'Neil, (Ed.). (2006). Fig (1) and losing by light, UV light, presence of heat, heavy metals and atmospheric oxygen (Bavaresco, 2003)So, this step to obtain as a much as could pure cinnamic acid during extraction in comparison with standard and steps for isolation cinnamic acid were:

\section{Acid Hydrolysis:}

Acid hydrolysis was done by using $\mathrm{HCl}$ $10 \%$ for (10-30) min in a water bath. This step led to hydrolysis glycosidic linkage and 
obtain the glycone moiety, after cooling and filtering the product (O'Neil, 2006).

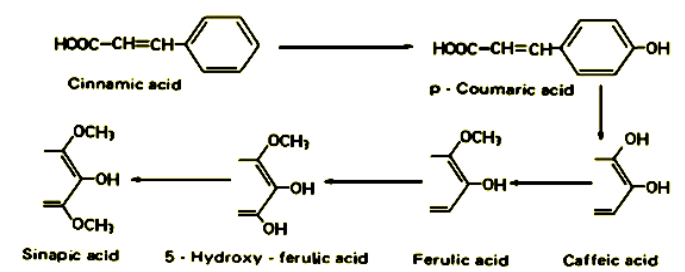

Figure. (1): Cinnamic acid when oxidized by light, UV or oxygen.

\section{Liquid-Liquid portion:}

The filtrate was transferred to separatory funnel. Chloroform was added in a quantity equal to the aqueous phase, shaking gently and repeating the process three times. The chloroform layers were collected and dried by rotary evaporator at $30^{\circ} \mathrm{C}$, viscous green residue was stored in dark umber vessel at $20^{\circ} \mathrm{C}$ until use (O’Neil, 2006).

\section{Column chromatography (partial purification):}

A partial purification of the residue was proceeded by using open glass column (20x 20) $\mathrm{cm}$ packaged by silica gel F60. The residue was dissolved in (1-2) $\mathrm{ml}$ methanol and the mobile phase was benzene: acetic acid: water (6:7:3) (O’Neil, 2006).

Eluted sample were collected in 50 separated tubes and collected as $3 \mathrm{ml}$ per each tube. All fractions were tested for $\mathrm{FeCl}_{3}$ $1 \%$ solution as a colorimetric method for polyphenols detection (O'Neil, 2006; Moffat, 2004) only the positive results were collected and dried under vacuum by a rotary evaporator. The cinnamic acid spots were detected on a TLC aluminum sheet silica gel $\left(60 \mathrm{~F}_{254}\right)$ in comparison with standard spot using the same mobile phase in the column chromatography. Cinnamic acid spots were examined with blue color spot under UV 254 lamb (O'Neil, 2006). The collected elution after drying was referred as "partial purification" for cinnamic acid.

\section{Preparation of Thin Layer Chromatography (TLC) (partial purification):}

TLC is a commonly used technique for the separation and identification of illicitly manufactured drugs. It is inexpensive, rapid, sensitive (sub-milligram quantities of analyze required), flexible in the selection of both the stationary and mobile phase and amenable to a wide variety of substances, in base and salt form, ranging from the most polar to non-polar materials(United Nations Office on Drugs and Crime, 2012).

The dried samples obtaining were subjected to another extraction such as hexane: dichloromethane solvent (1:9) to obtain red color according to solubility of phenolic compound and insolubility of cinnamic acid. The layers dichloromethane which collected and dried under vacuum at $30^{\circ} \mathrm{C}$ in darkness with rotary evaporator were ready for TLC analysis.

The TLC method was described by (Cannell, 1998; Moffat, 2004). The application of the extract was done after resolving in $3 \mathrm{ml}$ of solvent system, benzene: methanol: water (6:7:3). The chamber was saturated with vapors for one hour before running the samples. Silica gel glass plates without fluorescence were activated for 10 minutes at $115^{\circ} \mathrm{C}$.

It is done by using a micropipette for the sample application as a continues straight time to be loaded in a width rang (2-4)nm wide. The procedure was running on in a dark cool place, when the solvent system reached to the upper edge of the plate, removed and sprayed with:

I. Diphenylboiloxetilamine is a detector for cinnamic acid, examined after dried for few minutes, the pure cinnamic acid line appeared as a dark straight line (Gulab et al., 2005).

II. $\mathrm{ALCl}_{3} 1 \%$ ethanol solution get dark spot for both standard and extract cinnamic acid, then sprayed with starch $1 \%$ to fix the unsaturated compound with blue dark spots(Huiping \& Huang, 2002).

III. To visualize the fraction, sprayed small edge of the TLC plates with phosphomolibinin acid, then heated for $5 \min$ (Huiping \& Huang, 2002).

Th line was scraped and eluted with $10 \mathrm{ml}$ of methanol for three times and stored at $20 \dot{C}$ for 2 days. An amorphous off yellow green crystal formed and collected rapidly in cool dark place, then kept in umber reservoir at $20 \dot{C}$, these crystals were refer as "pure cinnamic acid ". The fraction that did not react was scraping off and extract with dichloromethane for two hours with constant stirrer (Gulab et al., 2005), then filtered and evaporated in a rotary evaporator under vacuum, weight and stored at $10 \dot{\mathrm{C}}$ until used. 
The crystals were examined with the following tests:

I. Thin Layer Chromatography: Spots was made from crystals and standard samples on plate of silica gel 60 with fluorescence and using benzene: methanol: water $(6: 7: 3)$ as a mobile phase.

II. High performance Chromatography (HPLC):

Liquid

A. Dissolved 4gm of standard cinnamic acid 99.9\% in 1litter methanol and made the concentrated $(1,2,3.2,6.75,12.5,25,50$, 100 and 200) ppm to get the stander curve (Huiping \& Huang, 2002).

B. Dissolved 4gm cinnamon extract in 1litter methanol and diluted to $(1,2,3.2$, $6.75,12.5,25,50,100$ and 200) $\mathrm{ppm}$.

Both standard and cinnamon extract were examined by HPLC with condition (Huiping \& Huang, 2002).

- The column was hypersil C18 (4.6X 250 $\mathrm{mm}, 5 \mu \mathrm{m})$.

- The mobile phase was: methanol: acetic nitrile : water : acetic acid (25:26:49:0.3).

- The flow rate was $0.1 \mathrm{ml} / \mathrm{min}$.

- The UV detector was set at $270 \mathrm{~nm}$.

III. Melting point process: Using melting point apparatus (Glascoo, U.K.) especially for this process. Cinnamic acid melting point ranges $(133-135){ }^{\circ} \mathrm{C}$ (Budavari, 2001).

\section{Results and Discussion:}

\section{The cinnamic acid extraction:}

Cinnamon bark were kept in a cool dark place, then $150 \mathrm{gm}$ of dried powder was hydrolyzed by hydrochloric acid and extracted with chloroform, then cinnamic acid separating by liquid-solid adsorption chromatography technique (silica gel column) to yield partial purified of cinnamic acid which eluted and isolated as crystals by TLC method. Pure crystals were about $10.5 \mathrm{mg}$ result from $150 \mathrm{gm}$ bark powder. Cinnamic acid was oxidized and converted to benzoic as Fig (1), by light, UV light, presence of heat, heavy metals and atmospheric oxygen (Bavaresco, 2003; O'Neil, 2006). The bark powder of cinnamon aromatic is rich with cinnamic acid derivates compounds (85\%) and bitty amount of eugenol (Al-Zubaidi, 2005).

The procedure for extraction was concluded different studies, all these processes have been carried out in the dark
(O'Neil, 2006). The bark powder was extracted with 2.5 litters methanol, because it's a good in many purpose solvent for preliminary extraction (Huiping \&Huang, 2002). The cinnamic acid was hydrolyzed with $10 \% \mathrm{HCl}(\mathrm{v} / \mathrm{v})$ in water bath for (10-30) min (Budavari, 2001).

Purification of Cinnamic acid:

The partial purification was done by the silica gel $\mathrm{G}_{60}$ column chromatography technique with a mobile phase benzene: acetic acid: water (7:6:3), then eluted fractions according to their affinity to mobile phase. The resultant fractions that gave positive ferric chloride test $1 \%$ solution were detected by TLC with silica gel $60 \mathrm{~F}_{254}$ plate and the same mobile phase (Cannell, 1998; Arce et al., 1998; Brandolini et al., 2002). as indicated in Fig (2).

Spot 1 and 3: $1 \mu \mathrm{l}$ of cinnamic acid standard solution $0.1 \%$.

Spot 2: $1 \mu$ of partial purified cinnamic acid gave positive results with $\mathrm{FeCl}_{3}$ solution $1 \%$ after column chromatography.

Spot 4: $1 \mu \mathrm{l}$ of extract after column chromatography gave negative results with $\mathrm{FeCl}_{3}$ solution $1 \%$.

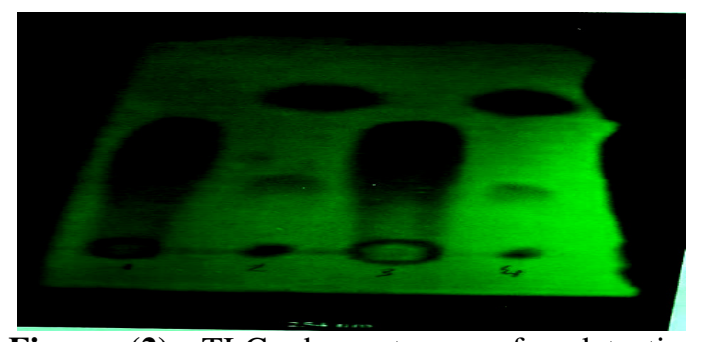

Figure (2): TLC chromatogram for detection partial purified cinnamic acid under UV lamp $(254 \mathrm{~nm})$ explained the positive and negative results with $\mathrm{FeCl}_{3} 1 \%$ test.

Figure (2) appeared fractions of positive result and standard fluorescence spots with (Retention factor) $R_{f}$ value $=(0.75)$, while the negative fraction were not. The dried collection was designed as "partial purified cinnamic acid. The cinnamon bark contains numerous amounts of chemical compounds, therefore, the extraction up is necessary by Liquid-Liquid partition technique for separation compounds according to the different distribution coefficients and the solvent affinity to solvents (Cannell, 1998). Dichloromethane is a good solvent for cinnamic acid taking up is viewing in many studies. 
TLC method can achieved separation less than microgram of material, while for large scale, TLC was considered as a good technique for isolation and purification to obtain purified components for grams amount, by using benzene : acetic acid : water (7: 6:3) as a mobile phase with silica G 60 glass plate $(0.75 \mathrm{~mm})$. Pure cinnamic cid line appeared as a dark straight line (the silica gel 60 was using without fluorescence).

Chemical Identification of Cinnamic acid:

Cinnamic acid (partial and pure crystals) was tested for general phenolic tests Table (3).

\begin{tabular}{|l|l|l|}
\hline \multicolumn{1}{|c|}{ Test } & \multicolumn{2}{c|}{ Result } \\
\hline $\begin{array}{l}\text { NaOH 5\% solution } \\
\text { (detected oxidation phenolic compounds) }\end{array}$ & $+\mathrm{ve}$ & Soluble \\
\hline $\begin{array}{l}\text { Sodium carbonate 5\% solution } \\
\text { (detected antioxidation phenolic compounds) }\end{array}$ & $+\mathrm{ve}$ & Insoluble \\
\hline Ferric chloride1\% solution (detection phenolic compounds) & $+\mathrm{ve}$ & Green color \\
\hline $\begin{array}{l}\text { Libermann reaction } \\
\text { (detection of phenolic compound with para position) }\end{array}$ & $+\mathrm{ve}$ & Red \\
\hline Phthalein reaction (phenolic compounds) & $+\mathrm{ve}$ & Red colour \\
\hline $\begin{array}{l}\text { Aluminum chloride test } \\
\text { (Friedle graft) (for the aromatic ring) }\end{array}$ & $+\mathrm{ve}$ & Yellow to orange colour \\
\hline $\begin{array}{l}\text { Bromine decolourisation test } \\
\text { (for the double bond) }\end{array}$ & $+\mathrm{ve}$ & $\begin{array}{l}\text { Discharge of reddish - brown } \\
\text { colour }\end{array}$ \\
\hline Baeyer test (for the double bond) & $+\mathrm{ve}$ & Disappears of the purple colour \\
\hline
\end{tabular}

Table (3). General phenolic compound tests. $*+\mathrm{ve}=$ positive.

\section{High Performance Liquid Chromatography (HPLC) for Cinnamic acid:}

HPLC is another major separation technique commonly used in forensic drug analysis. For ease of sample preparation, best reproducibility and detectability, reversed phase chromatography is recommended for the analysis (O'Neil, 2006).

External or internal standard calibration may be used. The use of peak area for HPLC quantitation is recommended, because peak broadening (decreases in peak height) may occur as a result of deterioration of the stationary phase, rendering peak height unsuitable for quantitation (United Nations Office on Drugs and Crime, 2012).

For cinnamic acid detection, HPLC method according to (Huiping \& Huang, 2002) was used with wave length: $280 \mathrm{~nm}$ for both cinnamic acid extract and the standard under the same conditions. Table (4), appeared peak area and retention area and the corresponding retention time in both cinnamic acid standard and extraction.

\begin{tabular}{|c|c|c|c|c|}
\hline Sample & Wave length & Concentration (ppm) & Retention area & Peak area \\
\hline $\begin{array}{c}\text { Standard } \\
\text { Cinnamic acid }\end{array}$ & $280 \mathrm{~nm}$ & $100 \mathrm{ppm}$ & 8.40 & 2653179 \\
\cline { 2 - 4 } & & $25 \mathrm{ppm}$ & 8.91 & 6214651 \\
\hline $\begin{array}{c}\text { Extraction } \\
\text { Cinnamic acid }\end{array}$ & $280 \mathrm{~nm}$ & $100 \mathrm{ppm}$ & 8.13 & 3614220 \\
\cline { 2 - 4 } & & $25 \mathrm{ppm}$ & 8.88 & 5910090 \\
\hline
\end{tabular}

Table (4). HPLC results for pure extracted and standard cinnamic acid (128 min).

Results emphasized that the conditions for extraction and purification occur in dark place, the study focus on qualitative specification of the cinnamic acid which is the proper way for extraction and application. Steps followed can be assumed for cinnamic acid qualitative study, such as
TLC method for purification and proved to be a high efficiency method, then the isolated substance was determined by the specific $\lambda \max$ and HPLC technique. Measuring both standard and extracted cinnamic acid at maximum wave length absorption and the retention time explained 
the selectivity and accuracy of the applied method (O'Neil, 2006).

\section{Melting point of cinnamic acid:}

The melting point was provided information about the purity of the substance. Pure crystalline solids have a sharp melting point temperature, but the mixture tends to melt at temperature below the melting point pure solids (Budavari, 2001). The melting point of cinnamic acid and the extracted are between the (133-135) $\dot{C}$ that reflects the purity of extraction cinnamic acid which gain from partial purification (United Nations Office on Drugs and Crime, 2012).

\section{Conclusion:}

1. The partial purification by column chromatography and TLC obtain white crystal of cinnamic acid yield $10.5 \mathrm{mg}$ from $150 \mathrm{gm}$ cinnamon bark powder in comparison with standard.

2. All general chemical tests of phenols showed positive results.

3. The purification of extraction cinnamic acid in HPLC was $96 \%$ in comparison with standard.

4. The melting point of extraction cinnamic acid showed $96 \%$ in comparison with standard.

\section{References:}

Gray, E.W., Miller, J.I. (1970). "The Spice Trade of the Roman Empire 29 B.C.-A.D. 641". The Journal of Roman Studies 60: 222-224.

Dastur, F. (1977). Cinnamonin: useful plants of India and Pakistan ( $8^{\text {th }}$ ed.). Taraporevela Sons and Co. privat LTD. p: 41-2.

Robert, K., Daryl, K., Peter, A. and Victor, W. (1996). Digestion and absorbition in: Harpers Biochemistry (th ed), Appelton and Lang, California. p:637.

Cannell, R.L.P. (1998). Natural Products isolation. Humana press. New Jersey.

Arce, L., Tena, M.T. and Valcarcel, M. (1998). Determination of transresveratrol and other polyphenols in wines by continous flow sample clean up system followed by capillary electrophoresis separation Analytica. Chimic. Acta. 359: 2738.
Al-Shamaa, Ali abdul-Gussein (1989). "Drugs and Chemistry of medicinal plants". Library of Printing and Publishing, Baghdad, p: 282.

Budavari, S. (2001). The Merck Index, (12 ${ }^{\text {th }}$ ed). Merck \& co., Inc. White house Station, N.J. USA.

Brandolini, V., Maletti, A., Tedeschi, P. and Manfredini, S. (2002). Capillary electrophoresis determination, synthesis and stability of resveratrol. J. Agrc. Food. Chem. 50: 74077411.

Huiping, D. and Huang, Ch. (2002). The active ingredient of Cinnamon extract and pharmacokinetic study. Hebei Medical University, 73 pages.

Jayaprakasha, G.K., Rao, L.J. and Sakariah, K.K. (2002). Chemical composition of volatile oil from Cinnamomum zeylanicum buds. Z. Natur Forsch[c]. 57 (11-12). 990-993.

Bavaresco, L. (2003). Role of viticultural factors on stilbene concentrations of grape and wine. Drugs Exp. Clin. Res. 29: 181-187.

Moffat, A.C., Osselton, M.D. and Widdop, B. (2004). Clarke's Analysis of Drugs and Poisons, 3rd Edition, Pharmaceutical Press.

Al-Zubaidi, L. Ah. (2005). Inhibition activity of bark cinnamon extracts against some microorganisms to be used in ground meat preservation, MS.C, Genetic Engineering and Biotechnology Institute for Postgraduate Studies, Baghdad, Iraq.

Chen, M.J., Jaykumar, V., Lu, B.W., Xia, B., L.I., N. (2005). J. Integr. PlantBiol., 47, 67-72.

Gulab, N., Jham, I., Onkar, D., Dhingra, I., Caolina, M., jardimI. and Vânia, M. (2005). Identification of the major fungitoxic component of cinnamon bark oil.Universidade Federal de Viçosa, Viçosa, vol. 30, no: 4.

Camarat, M., Galaction, A. and Cascaval, D. (2006). Separation of trans-cinnamic acid by reactiove extraction with Amberlite LA-2in low -polar solvent.Roumanian Society of Biotogical Sciences; 11(5): 28972903. 
O’Neil, M.J., (Ed.). (2006). The Merck Index: An Encyclopedia of Chemicals, Drugs, and Biologicals, 13th Edition, NJ: Merck.

Mousa, Nibal, Kh., Labeeb, Ah., AlZubaidi, Ishrak, Ab, A. (2011). Evaluation Toxic oxidant activity for pure cinnamic acid in albino mice,Journal of Madenat Alelem College, 3 (2) 34-4.

Mousa, Nibal, Kh., Labeeb, Ah., AlZubaidi, Iman, I., Qatia, Ishrak, Ab,
Ahmed.

(2011).

Biochemical,Hepatoprotective

Effects of pure cinnamic acid Against Cyclophosphamide in white mice,Journal of Madenat Alelem College, 3 (2) 45-65.

United Nation Office on Drugs and Crime, (2012). Recommended Mthods for Identification and Analysis of cocaine in seized Material.United Nation, New York, pages: 48.

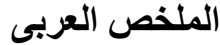

كروموتوغرافيا الطبقة الرقيقة وكروموتوغرافيا السائل العالي الأداء ودرجة الانصهار

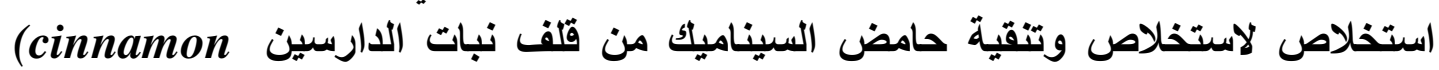
aromaticum)

نبال خليل موسى'، عبد الجبار عبود عبو '، صفاء الدين عدنان عبد الرحيم'، إثراق عبد الأمير علي'، عقيل ماجد احمد'

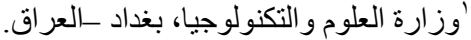
'المركز الوطني للرقابة والبحوث الدو ائية، وزارة الصحة. بغداد_العراق.

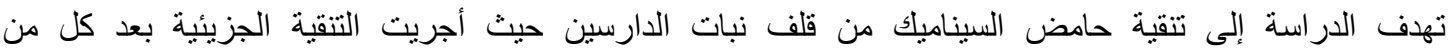
كروموتوغرافيا العمود كروموتوغر افيا الطبقة الرقيقة (TLC)والتي أعطت طبقة كرستالية رقيقة لحامض السيناميك

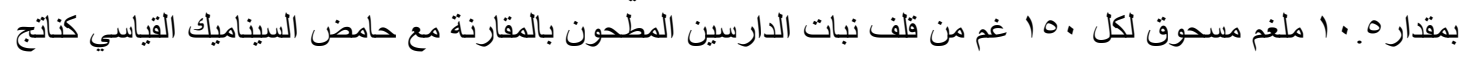

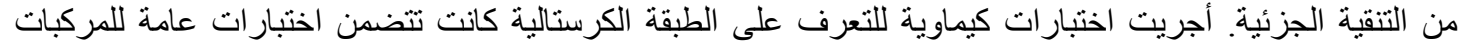

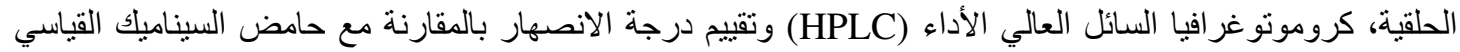

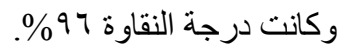

